\title{
Short communication: The crustaceans fauna from Natuna Islands (Indonesia) using three different sampling methods
}

\author{
RIANTA PRATIWI ${ }^{1, \vee}$, DEWI ELFIDASARI ${ }^{2, \bullet \vee}$ \\ ${ }^{1}$ Research Centre for Oceanografi, Indonesian Institute of Sciences. J1. Pasir Putih 1, Ancol Timur, Jakarta Utara 14330, Jakarta, Indonesia. \\ Tel.: +62-21-64713850, Fax.: +62-21-64711948, `email: r_pratiwi_99@yahoo.com or pratiwiafriadi@gmail.com \\ ${ }^{2}$ Department of Biology, Faculty of Sciences and Technology, Universitas Al-Azhar Indonesia Jl. Sisingamangaraja Kebayoran Baru, South Jakarta \\ 12110, Jakarta, Indonesia. Tel./fax.: +62-21-72792753, ^^email: d_elfidasari@uai.ac.id
}

Manuscript received: 21 November 2019. Revision accepted: 25 February 2020.

\begin{abstract}
Pratiwi R, Elfidasari D. 2020. Short communication: The crustaceans fauna from Natuna Islands (Indonesia) using three different sampling methods. Biodiversitas 21: 1215-1226. Research on crustacean fauna has been carried out in Natuna waters. Natuna is the outer islands of Indonesia which is still very abundant in fisheries resources including crustaceans. Unfortunately, research on crustaceans is rarely carried out there, especially on the islands around Natuna. Therefore research and information about fisheries, especially crustaceans are needed. The study was conducted on 12-29 April 2011 and sampling locations around the Bunguran Islands, Sedanu, Kognang, Batang, and Sebangmawang. The sampling collection was focused on three different sampling methods, namely: bottom trawling, transects, and free collection. The purpose of this study is to find out which method is best used in crustacean fauna research and it is expected that the crustacean data obtained can add information about crustacean fauna found in the Natuna Islands. Crustacean fauna, which were collected, showed that species from basic trawlers numbered 66 species, 41 species were from transects and 101 species was from free collections. The total number of individuals from the bottom trawl were 746, from the transect were 65 and from the free collection were 704. From the results of the study using three different methods have advantages and disadvantages of each method. The best method used is the free collection method and bottom trawling, because it can collect many crustacean species.
\end{abstract}

Keywords: Batang Island, bottom trawl, Bunguran Islands, free collection, Kognang Island, Sedanu Island, Sebangmawang Island, transect

\section{INTRODUCTION}

Natuna Regency is an archipelago consisting of 272 islands and is located in the southern part of Natuna Island, South China. Administratively, this island is included in the Riau Islands Province. Natuna is the northernmost island in the Karimata strait and stretches at $4^{\circ} 0^{\prime} 0$ "LU and $108^{\circ} 15^{\prime} 0^{\prime \prime}$ East, about $1,140 \mathrm{~km}$ north of Jakarta. The islands are bordered by Vietnam and Cambodia (North), South Sumatra and Jambi (South), Singapore, Malaysia, Riau (West) and East Malaysia and West Kalimantan (East). The largest island in the Natuna archipelago is Bunguran Island (Mirmanto 2014). The Natuna Islands are part of the Sunda shoal, which has oceanic characteristics with a depth of no more than 200 meters and overgrown with corals that form coral reefs (Widyastuti 2016).

Crustaceans are a group of important macrobenthic fauna in coastal ecosystems, ranging from mangrove ecosystems, coral reefs, and seagrass ecosystems. These animals play a very important role in ecosystems with life activities such as foraging, digging, spawning, in the cycle of nutrition, and energy flow (Kathiresan and Bingham 2001; Hamidy 2010; Widyastuti 2016). In addition, crustaceans are also one of the most important members of the benthic fauna community living in tropical and subtropical regions. Crustacean faunas play an important role in the maintenance of marine ecosystems where larger species of groups control the populations of other species and provide important food for human consumption. Smaller crustacean species increase habitat diversity and provide a prey base for larger species (Trivedi et al. 2015).

The Natuna Islands coastal area supports a variety of marine habitats such as mangrove forests, coral reefs, seagrasses, rocky beaches, mud, sandy beaches, and estuaries, which on the other hand support rich marine biodiversity. Many researchers have conducted different studies related to marine biodiversity in Natuna waters. Crustacean studies conducted in Natuna waters are not many, of them were conducted by Li (2004), Yeo et al. (2004), Ahyong and Moosa (2004), Widyastuti (2007). Among the various marine fauna that occurs in the Natuna waters, the crustacean fauna is the least studied group. Therefore, data and information regarding the existence of crustacean fauna are still not widely found.

In this study of the fauna crustaceans, three different methods were used for sampling. The data obtained were analyzed, with three different methods, it is expected to know which method is very well used and suitable for ecological research in Crustacea and can preserve the environment. However, this research is a preliminary study (preliminary research) in order to obtain deeper information so that it can support further research on crustaceans in the future. 


\section{MATERIALS AND METHODS}

The species of crustacean presented in this paper were collected during the 2011 in the Widya Nusantara Expedition carried out on Natuna Island. This expedition used the research vessel Baruna Jaya VIII owned by the Indonesian Institute of Sciences. The sampling locations were the Bunguran Islands, Sedanu, Kognang, Batang, and Sebangmawang, Natuna Islands, the southern South China Sea (Figure 1). Collections were carried out from various habitat types using different collection methods, e.g.: hands, free collection, transects, and trawls (bottom trawls). However, this paper only used data from trawlers, transects, and free collections while other data were not discussed. In addition to knowing the fauna of crustaceans, this study was also used to find out what species were captured during the study using three different methods. The aim of this is to know what is the best method appropriate for this research.

The obtained samples were then sorted at the Oceanographic Research Center-LIPI. The samples put into a bottle and preserved with $70 \%$ ethanol. Individual counters and identified using reference books for crabs and shrimp by Holthuis (1955), Hall (1962), Banner and Banner 1966; Sakai 1976; Burukovskii 1982; Banner and Banner 1982; Banner and Banner 1985; Kim and Abelle 1988; Rahayu and Davie 2002; Pratiwi 2002; Wicksten and Maclure 2007; $\mathrm{Ng}$ et al. 2008; Prodam and $\mathrm{Ng} \mathrm{2009;}$
Rahayu and Setyadi 2009; Schubart et al. 2009; Wong et al. 2011). Crustaceans obtained are grouped and sorted into their respective families and identified by reading the identification keys. After the species is known, the next step is to photographs. The photographs and drawing were taken on these species and carried out a description of the parts of the body that are character identification species. The Specimen depiction were using Camera Lucida

\section{Bottom trawlng (a sweep method)}

Crustacean sample collections were carried out using demersal trawl (bottom trawl) with the width of $22 \mathrm{~m}$ mouth opening, 2/3 mouth opening arches, and $130 \mathrm{~m}$ long rope. Sampling by trawling is carried out three times, at trawl 1/station 14 (Sedanau Island), trawl 2/ station 16 (Batang Isand) and trawl 3/station 20 (South Station Bunguran Island). Station 14 with a depth of 46 meters, station 16 with a depth of 37 meters, and station 20 with a depth of 30 meters. Start towing to start hauling is 1 hour with an area that varies depending on the depth and existing substrate. After hauling is pulled back, all the biota is laid out on the back deck for sorting. The catches are then sorted by group, (family) which is then stored in a container for identification in the laboratory. After that all species obtained by the trawl method we put together into one place (big freezer).
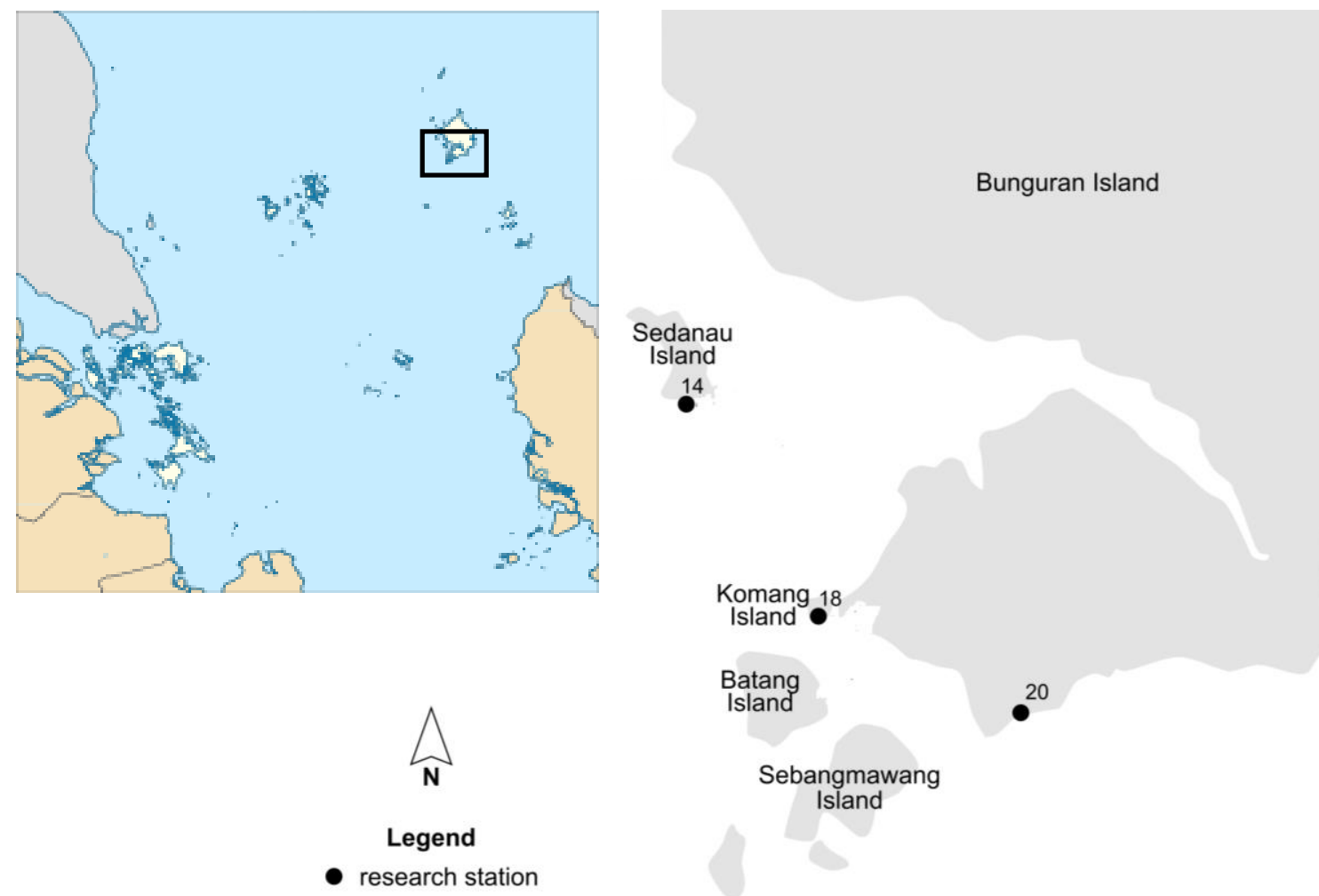

- research station

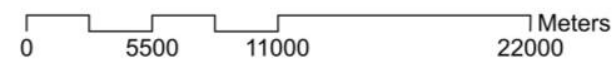

Figure 1. Location of sampling fauna of crustacean at Natuna Island, Indonesian 


\section{Transect method}

Transects conducted perpendicular coastline, which starts from the shore towards the edge, depending on tidal conditions. A transect line can be made using a nylon rope or roll meter marked and numbered at $10 \mathrm{~m}$ intervals, all the way along its length. At each distance of $10 \mathrm{~m}$, put the quadrats measuring $1 \times 1 \mathrm{~m}^{2}$, which was randomly placed. Transects were carried out three times in Bunguran, Sedanu, Kognang, Batang, and Sebangmawang Islands. The existing crustaceans on the surface of the substrate were taken by hand (hand picking), and those contained in the hole were taken by digging the hole using a shovel. Excavation to a depth of $\pm 10 \mathrm{~cm}$ was also carried out to collect the living crustaceans, which immerse themselves in the substrate. The number of individuals and species of each crustaceans in the square were recorded. This sampling method was adapted from the method used by Sasekumar (1974), Frith et al. (1976), and Kathiresan et al. (2016).

\section{Free collections}

The free collection method is done by breaking stones, digging holes, using fishing gear such as hand net, hammer, and hand. When found a living coral or dead corals, breaking down corals using a hammer to carried out the crustaceans that living in side the corals. After crustaceans are found, recorded, and marked, their location position were recorded by using GPS Garmin 76sx. Free collections were carried out in Bunguran, Sedanu, Kognang, Batang and Sebangmawang Islands. Sampling is done freely as many as three people and for 2 hours. Samples were taken randomly, where rocks were found. Once a coral reef is found, the coral will be broken, crustaceans were taken inside and recorded its location. The collected specimens were stored in samples bags, labeled, and stored in the freezer until the photography session and to be further identified. Afterward, they were fixed in $96 \%$ ethanol overnight to ensure the whole specimen bodies were completely preserved. The overnight samples were exposed to $70 \%$ ethanol for longer preservation. All preservation methods were carried out the same way for samples from trawlers transects and free collections. The crab collections were conducted during the low tide to make the collection easier (Katili et al. 2017).

\section{RESULTS AND DISCUSSION}

Based on the results of the study, the total number of 66 species of crustaceans were obtained from bottom trawls, 41 species were obtained from transects and 101 species were obtained from free collections. While the total number of crustacean individuals was 746 individuals from bottom trawls, 65 individuals from transects and 704 individuals from free collections (Table 1 and Table S1). There are only three species of crustaceans obtained from the three methods used, namely: Alpheus facetus, A. rapax, and Thalamita crenata (Table 2).

\section{Composition of number species and number of individuals crustaceans using trawl, transects, and free collections}

In terms of the number of crustaceans obtained by trawling, transect, and free collection methods, there are different numbers of species and individuals (Table 1). This is because the retrieval of sampling using different methods and tools. The trawl retrieval is adjusted to the conditions when the trawl towing. The trawl depth of about 20 to $30 \mathrm{~m}$. When seen from the results obtained (Table 1) the number of crustacean species is only 66 species, but the number of individuals is 746 individuals, this happens because when trawling is done at night these species usually come out and gather to look for food. In addition, the species of crustaceans that are obtained that indeed living in the depths.

Meanwhile, the transect method is carried out at low tide, using a $1 \times 1 \mathrm{~m}^{2}$ transect frame that is carried perpendicular to the beach using a length of rope that depends on the length of the beach. In this case the length of the beach ranges from 150 meters to 300 meters. With this transect method not many species of crustaceans are found because not all crustaceans are in the transect frame. This is also because crustaceans are very mobile and getting into the hole quickly so it is very difficult to find. Thus a very small number of species and the number of individuals obtained by this method.

Whereas free collection, carried out in the coastal area at low tide by breaking the coral found and the location chosen randomly. With this method more species and numbers of individuals are obtained from the species of crustaceans, because it is not limited to the transect frame and the location is determined randomly.

\section{Species of crustacean discovered by using three sampilng methods}

Three species discovered in all of sampling methods consisted of two families. Alpheus facetus and A. rapax are shrimp belonged to the family Alpheidae. Whereas, the species of crab, $T$. crenata, belongs to the Family Portunidaea. Based on the results of research using these three methods, three species of crustaceans were found. Two species come from the Alpheidae family, which are species of pistol shrimps that live in symbiotic in corals, seagrass beds and mangrove. It has a very small size, only a few $\mathrm{mm}$ and cannot be eaten, therefore it has no important economic value (Pratiwi 2006). This species of Alpheus shrimp inhabits various habitats on coral reefs in both the tropics and sub-tropics. Most of these species are found living in the coral colonies and/ or hide under dead rock corals. These species like clear waters (Pratiwi 2002; Bezerra and Almeida 2008). Several species of Alpheidae can also be found in the intertidal depth range up to 130 meters (Chace 1988). 
Table 1. The composition of number species and number of individuals from crustaceans using three different methods

\begin{tabular}{lccc}
\hline Methods & Trawl & Transect & Free collections \\
\hline Total number of species & 66 & 41 & 101 \\
Total number of individu & 746 & 65 & 704 \\
\hline
\end{tabular}

Table 2. Species of crustacean discovered using three methods

\begin{tabular}{llcccc}
\hline \multirow{2}{*}{ Family } & Genus/spesies & Trawl & $\begin{array}{c}\text { Sampling methods } \\
\text { Transect }\end{array}$ & Free collections & Total \\
\hline Alpheidae & Alpheus facetus de Man, 1908 & 1 & 4 & 9 & 14 \\
& Alpheus rapax Fabricius, 1798 & 3 & 1 & 1 & 5 \\
Portunidae & Thalamita crenata Rüppell, 1830 & 3 & 2 & 19 & 24 \\
\hline
\end{tabular}

Another species is T. crenata which is a species of crab belonging to the family Portunidae. The habitat of the T.crenata is broken coral sand and the bottom of the sandy sand waters, with depths between 25 and $30 \mathrm{~m}$ (Dai and Yang 1991), but this species is found only slightly in shallow non-reef habitats with soft substrates. Although it is a commercial species, not all Indonesian people eat it and sell it. Fishermans usually eat for the needs of their family.

\section{Synopsis and identification of three species crustaceans}

Phylum: Arthropoda

Subphylum: Crustacea

Class: Malacostraca

Order: Decapoda

Family: Alpheidae

Genus: Alpheus

\section{Alpheus facetus de Man, 1908}

Alpheus facetus (Fig. 3) belongs to the Macrochirus group. The local names of this species is "Udang pistol". This shrimp has a small body size that is $18.0-23 \mathrm{~mm}$ body length and 7.0-11 mm carapace length. The rostrum is pointed (acute), with the tip of the rostrum reaching to the front of the end of the first antenna segment. The carina spine is blunt and rounded slightly wider posteriorly and extends almost to the center of the carapace. Orbital hoods (parts of the eye) have sharp (acute) teeth at each end (anterior margin) and have a shorter size than rostrum.

The antennules having an antennular peduncle length (antenna stalk) is almost the same and with all three-ratio ratios compared to: 0.3: 0.5: 0.3. The Stylocerite section (the inside of the antenna) is slim, with a sharp (acute) lateral part reaching the middle of the second antenna segment. The Scapocerite part (part of the antenna) has an edge (lateral margin) in a straight shape with lateral teeth that exceeds the length of the third segment of the antenna, and lamellae. The Carpocerite (part of the antenna) is hard and exceeds the size of the antennules. While Basicerite armed has acute tooth The segment of the third maxilliped has a ratio: 10: 5: 15, with a narrow shape and at the edges there are hairs attached along the edge of the tip.
The major chela (Large claws) of shrimp A. facetus, large, flat and elongated. The superior margin supports two longitudinal ridges. Inferior margins are round without curves or grooves. Dactylus (part of a claw) is blunt, has movable fingers, and is slightly longer in size than immovable fingers. Merus (part of a claw) has 4-6 small spines and small pointed teeth (acute).

The minor chela (Small claws) have a slim shape with a sharp (acute) Dactylus. Carpus (small claw part) slim. Merus is unarmed and Ischium is bearing acute movable spine. This shrimp has a sharp (acute). Telson (tail part) in the posterior margin has acute shape. While in the middle of the telson (posterolateral) there are four spines (a pair of spines) that are slim and elongated. The uropodal endopod (the inside of the tail) and the uropodal exopod (the outside of the tail) are elongated with a large and sturdy spine in the external part.

This species has been collected from intertidal to depths of $30 \mathrm{~m}$, but most specimens have come from dead coral heads collected in $2 \mathrm{~m}$ or less depths. This species is new records from the Natuna Islands.

\section{General distribution:}

Alpheus facetus has distribution in the Western Indian Ocean, Vietnam, Thailand, Philippines, Indonesia, Japan Australia and Caroline Islands (Banner and Banner 1982; Chace 1988). Specifically, distribution in Australia was found in Western Australia near northern Perth to Yampi Sound and North Australia from Darwin, Gulf of Carpentaria and Islands on Thursday; in eastern Australia from south Port Douglas to near Sydney and New South Wales (Banners and Banners 1982. While the distribution of this shrimp in Indonesia, according to de Man 1911; Tiwari 1963 starts from Jedan Island, East Coast of Aru Islands and Paging Island.

\section{Indonesian distribution}

We have 14 specimens from Pulau Burung, Kepulauan Seribu; collected from intertidal and muddy substrate; 11 from Lancang Island, Thousand Islands from muddy substrate; 20 specimens from Bokor Island, Jepara, collected from muddy substrate and 7 specimens from 
Situbondo (Pasir Putih), collected from muddy substrate (Pratiwi 1999; 2002); One specimen from Hative Besar Island, Ambon, collected overground coral by Banner and Banner, 1975 (Banner and Banner 1985). In addition we got 14 specimens in the form of new records obtained from Natuna waters, i.e Sedanu Island, Bunguran Island and Batang Islands, from sand, coral, coll. Pratiwi 4/23/2011. All speciemen are stored well in the Reference Collection room of the Oceanography Research Center (P2O)Indonesian Institute of Sciences, Jakarta.

\section{Alpheus rapax Fabricius, 1798}

Alpheus rapax (Fig. 3) is the member of Brevirostris Group. The local names of this species is "Udang pistol". These specimens are medium size, measuring 19.0-26.0 $\mathrm{mm}$ in carapace length and 32.8-55.9 $\mathrm{mm}$ in body length. The rostrum is acute not reaching end of first antennular segment. The dorsal carina spines are acute and sharp in anteriorly and rounded in the posteriorly. Orbital hoods (part of the eyes) are unarmed, inflated, and rounded anteriorly. Orbitorostral groove deep and broader. The antennular segment of peduncle (antenna stalk) has ratio 0.4-0.9: 1.4-2.3: 0.5-0.9. The Stylocerite section (the inside of the antenna) has an acute tooth reaching almost near end of first antennular segment. The scaphocerite part (part of the antenna) has an acute lateral tooth reaching past end of third antennular segment. The lamella is broader and lateral margin are slightly concave. The scaphocerite is longer than carpocerite. The Carpocerite is strong and slender reaches the end of antenular peduncle. While Basicerite armed has acute tooth. The segment of the third maxilliped has ratio: $10: 4-5: 12-15$.

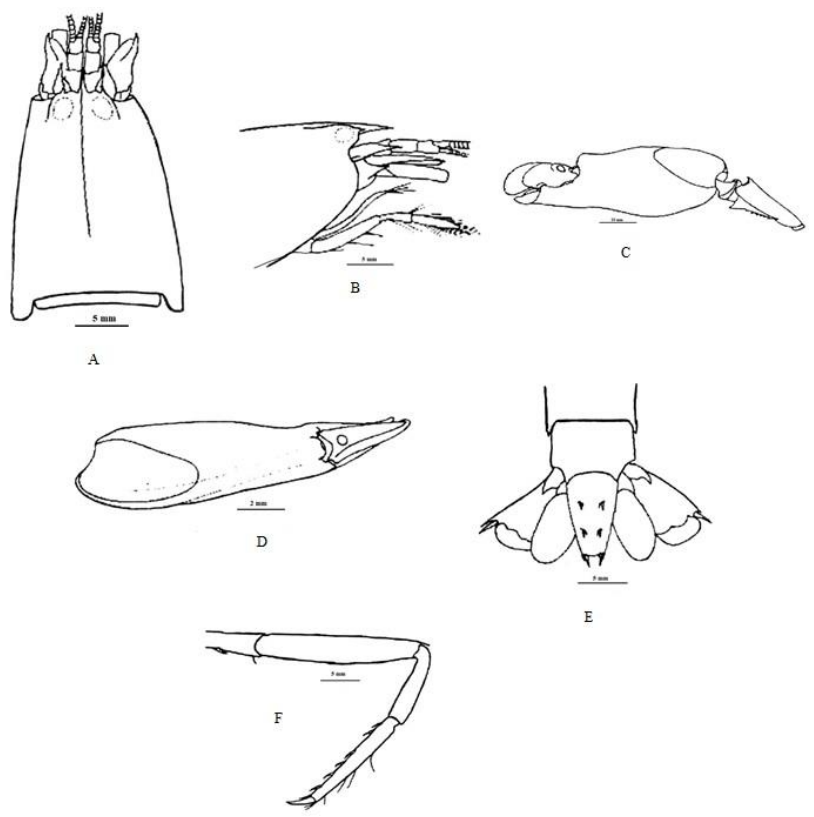

Figure 2. Alpheus facetus from Natuna Islands. A, B. anterior region, dorsal and lateral view; C, D. large chela and merus, lateral and dorsal view; E. telson and uropods, dorsal view; F. third leg (in $5 \mathrm{~mm}$ scale), lateral view.

The major chela (Large claws) of shrimp A. rapax is compressed with rounded transverse groove proximal to dactylus on superior margin, which is moderately flattened and bearing long forward hairs. Inferior margin is also flattened on palmar and bearing row of long forward hairs extends to distal of finger. Dactylus compressed bearing long forward hairs similar to propodal finger. Merus with superior distal is truncated inferior distal with acute tooth and bears 6-7 spines and are scattered long setae.

The minor chela (Small claws) is compressed shows sexual dimorphism, but without balaeniceps shape on both sexes. Dactylus is moderately curved at tip and with dense row of bristles on opposing faces fringed and cutting edges on both margin of fringer. Superior and inferior margin bearings forward hairs. Merus is similar with large chela. The ischium of this chela is armed with a small and acute tooth sub-distally.

Telson (tail part) in the posterior margin has rounded shape. While in the middle of the telson (posterolateral) there are four spines (a pair of spines) that are slim and elongated. The uropodal endopod (the inside of the tail) and the uropodal exopod (the outside of the tail) are elongated with a large and sturdy spine in the external part.

\section{General distribution:}

Alpheus rapax distributes in South and East Africa, Zanzibar, Djibouti, Madagascar, Red Sea, Maldives Archipelago, Ceylon (Sri Lanka), Mergui Archipelago (Andaman Sea), Indian Ocean, Netherlands, Indies, Singapore, Indonesia, Thailand, Australia, Japan, Mariana and Marshall Islands and Hawaii (de Man 1911; Barnard 1950; Banner and Banner 1982).

\section{Indonesian distribution}

We have 8 specimens from Burung Island, Thousand Islands collected from intertidal and muddy substrate; 3 specimen from Lancang Island, Thousand Islands, collected from muddy substrate; 2 specimen from Bojonegoro, Banten Bay, collected from muddy substrate; one specimen from Lima Island, Bunten Bay, collected from muddy substrate. 4 specimen from Bokor Island, Jepara, collected from muddy substrate. 9 specimens from Pasir Putih, Situbondo, collected from muddy substrate (Pratiwi 1999; 2002). 5 specimens from Sedanu Island, Bunguran Island and Batang Islands, Natuna (as New records), collected from sand, coral, coll. Pratiwi 4/23/2011. All speciemen are stored well in the Reference Collection room of the Oceanography Research Center (P2O)-Indonesian Institute of Sciences, Jakarta.

Phylum: Arthropoda

Subphylum: Crustacea

Class: Malacostraca

Order: Decapoda

Family: Portunidae

Genus: Thalamita 

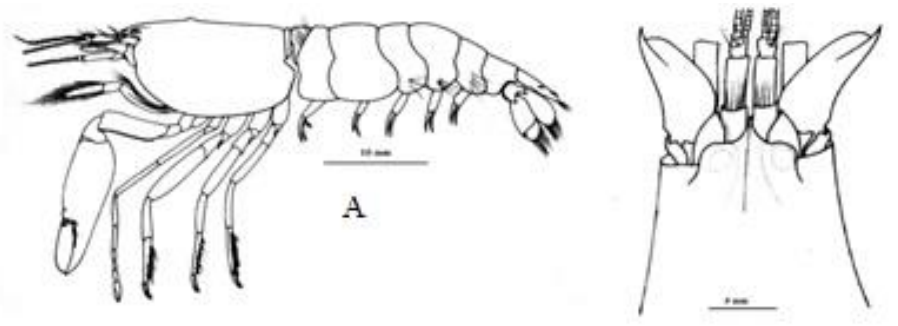

B

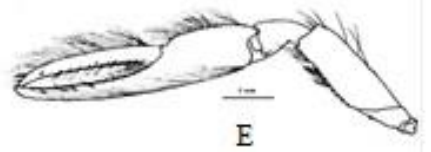

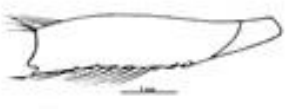

F

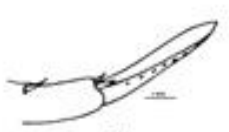

G
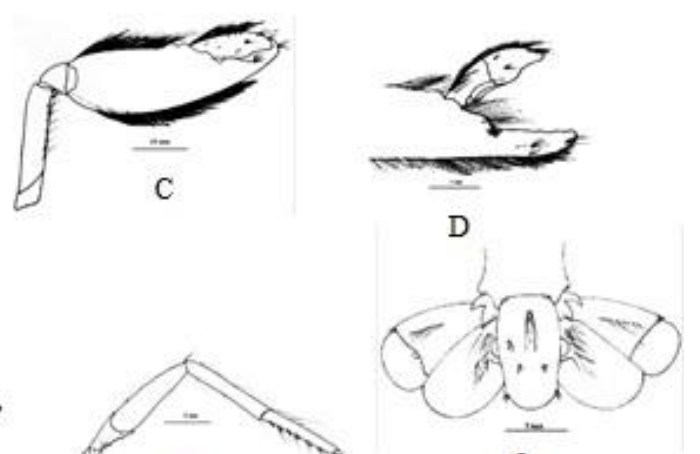

I

Figure 3. Alpheus rapax from Natuna Islands. A. Hole body of male, B. Anterior region, dorsal view, C. Large chela and merus lateral view, D. Enlarged large chela, medial view, E. Small chela and merus, lateral view. F. Merus of large chella, medial view, G. Enlarged dactylus, lateral view $\mathrm{H}$. Third leg, lateral view, I. Telson and uropods, dorsal view.
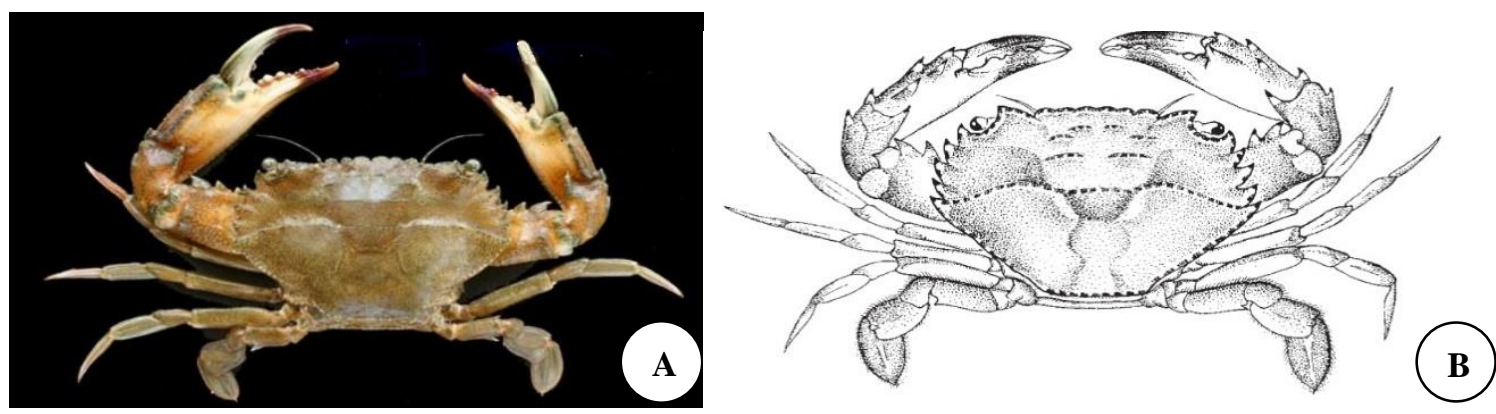

Figure 4. Photo (A) and sketch (B) of Thalamita crenata from Natuna Islands

Thalamita crenata Rüppell, 1830

The local name of this species is "Kepiting Batu". This crab has a size of more than $8 \mathrm{~cm}$ in carapace area. This species is also known as swimming crab, with a pair of fourth legs flattened into a paddle-like structure for swimming. The carapace is smooth in structure, with some low ridges present across the middle section. The claws are thicker and shorter than those of the blue swimming or long-eyed crab. There are five teeth along the front margin of the carapace, with the front teeth slightly larger than the last teeth. The species is identified by the six rounded lobes, nearly equal in size, along the anterior margin of the carapace between the eyes, and by five fine sharp spines on the antero lateral margin. The chelipeds or pincers are large and strong.

The habitat of $T$. crenata is the mud flat, muddy beach, river mouth, mangrove area, broken coral sand and the bottom of the sandy sand waters etc. with depths between 25-30 m (Dai and Yang 1991). It seems to prefer brackish water but is seldom found in clear seawater like coral reef. This middle-sized crab is mostly caught with baby trawlers, skimming netters or crab traps in the inner portion of a bay or mangrove creek. This species is very popular both for sale and consumption. They are caught by crab traps, often sold in fish market in southern of Sulawesi and Ambon Island, but in Jakarta this species is only consumed for local fishermen's families. T. crenata is one of the most distinctive species of the genus, and one of the few found in shallow non-reef habitats with soft substratesGeneral distribution:

Thalamita crenata is distributed in the entire tropical Indo-Pacific area from Hawaii soutward and westward across the tropical western Pacific Ocean, through East Indies and across the Indian Ocean finally reaching the coast of Africa and the Red Sea. China, Indonesia, Malaysia,Singapore, Australia, Tuamotu, Tonga, French Polynesia, and Hawaii.

\section{Indonesian distribution}

Mysore Island, Cendrawasih Gulf, Papua (de Man 1902); near Padang, Sumatera; Ujung Pandang, south of Sulawesi (de Man 1892); Ternate (de Man 1902); Ambon and Banda islands (Stephenson 1972); Haruku Island; Hoga Island, Kaledupa, Tukang Besi Island (Stephenson 1975) Southeast Sulawesi; Kepulauan Seribu (Pari Island, Ayer island, Nusalenga island, Kongsi island, Lancang Kecil island, Macan island, Pamagaran island, Pancalirang island dan Sebaru Besar island); Kamojan island, Karimunjawa island; Saubi island, Larat island, Kangean island; Sesil island; Tomea island, Nusa Tenggara Barat island; Saumlaki island; Jinatu island; Komodo island; Tajandu island, Aru islands; Kate-kate island, Ambon bay and Panarikan bay, Belitung; Mawi bay; Arafura Ocean; Maratua, Northeast, Kalimantan; near Manumbai, Hainsisi, 
Semau, near Timor island; Sapuka Besar; Postiljon islands; Bima island, Sumbawa island; Pankaja, Spermonde islands; Taliabu, Sula island, east of Sulawesi (Moosa and Juwana 1996). Sedanu Island, Bunguran Island and Batang Islands, Natuna (a neew record), sand, coral, coll. Pratiwi $4 / 23 / 2011$.

\section{The species of crustacean discovered in deep habitats (trawling)}

The results from trawling that conducted tree times at Sedanau Island, Batang Island, and South Station Bunguran Island obtained 66 number of species and 746 number of individuals (Table 3 and Table S2). From these results, it appears that there are some species that usually found in habitats with a depth of 20 to 46 meters. Penaeidae has the highest individual compared to other families. Metapenaeopsis palmensis (Haswell, 1879) with 246 individuals are found to be abundant in all stations (trawling) with adult and juvenile stages. Majidae (crab) is the second highest individuals after Penaeidae, with Phalangipus hystrix (Miers, 1886) (83 individuals). While Metapenaeopsis andamanensis (Wood-Mason in WoodMason \& Alcock, 1891) with 63 individuals and Charybdis callianassa (Herbst, 1789) (Portunidae) with 52 individuals (Table S2). Shrimps and crabs are one of the demersal fisheries, which means demersal fisheries related to both types are fishery products ranging from the coast to a depth of approximately 40 meters. The species of shrimp Penaeidae and Portunidae crabs found at the research station are also demersal fisheries (Nirmala and Pratiwi 2011).

The abundance of shrimp Penaeidae, Metapenaeopsis palmensis (Haswell, 1879), Metapenaeopsis andamanensis (Wood-Mason in Wood-Mason \& Alcock, 1891) in all stations because the environmental conditions are very supported for life. The temperature ranges are $29^{\circ} \mathrm{C}-31^{\circ} \mathrm{C}$ with an average of $30^{\circ} \mathrm{C}, 19^{\circ} \%-32{ }^{\circ} \%$ salinity with an average of $30^{\circ} \%, \mathrm{pH} 7.9$ to 8,9 and the average at the station is 8.8. Oxygen at the study site was 1,605-4,442 $\mathrm{ml} / \mathrm{L}$ with an average of $3,957 \mathrm{ml} / \mathrm{L}$ and was found at a depth of 40 to 45 meters. This is strongly supported by crustacean research in other Indonesian waters, where the optimal temperature range for crustaceans is around $28^{\circ} \mathrm{C}$ $30^{\circ} \mathrm{C}$, optimum salinity ranges are from $23 \%-32 \%$, and optimum pH is 7.4-8.5 (Romimohtarto and Yuwana 2001; Alfitriatussulus 2003; Pratiwi 2010; Nirmala and Pratiwi 2011). According to those researches, the temperature, salinity, $\mathrm{pH}$, oxygen and depth at each research station can still be tolerated by the crustaceans for survival. Supply of freshwater and sediment from the mainland or river flow are also very influential on the lives of shrimp (Penaeidae), especially the study site near the mainland of the island of Natuna, which is heavily influenced by the rivers around the Natuna Islands. Toro and Soegiarto (1979) state that shrimp live as benthic on the seabed. The most preferred habitat by shrimp is the seabed, which has a soft substrate (a mixture of mud and sand) because it can fulfill fertility in the area.

According to Pramonowibowo et al. (2007), based on its life cycle, all shrimp larvae and juvenile phases live in shallow waters and along with the development of the body. The shrimps will migrate to deeper waters and they choose an area with base substrate where corresponds to their life. Such is the case with the Portunidae, Charybdis callianassa (Herbst, 1789) and Majidae, Phalangipus hystrix (Miers, 1886) crab with the appropriate environmental conditions, will be supportive of their lives so that, their presence at each station will vary depending on the environmental conditions in which they are located.

Crustaceans obtained in Natuna waters have different numbers of individual crustaceans at each station this is influenced by differences in water environmental conditions. Station 14 has the highest number of individuals (410 ind./ha) and station 16 has the lowest number of individuals (125 ind./ha) when compared to station 20 which has the number of 211 ind/ha (Table 3 ).

\section{The species of crustacean discovered in shallow habitats (estuarine)}

The results of research conducted in shallow areas (estuarine) using transect and free collections methods in Bunguran, Sedanu, Kognang, Batang and Sebangmawang Islands, found that the species of crustaceans commonly found in areas with substrate sand, mud and muddy sand. Both methods are carried out at low tide, so that sample collection can be done easily.

The results of free collections have more species of crabs (101 number of species and 704 numbers of individuals) and there are 6 dominant species obtained from mangrove (mud substrate), seagrass (sand and mud sand substrate) and also in sandy beach areas (Table S4, Figure 3 and Figure 4). These species are Parasesarma plicatum (Latreille, 1803), Parasesarma pictum (De Haan, 1835), Ocypode ceratopthalmus (Pallas, 1772), Pagurus sp. Coenobita rugosus $\mathrm{H}$. Milne Edwards, 1837 and Thalamita crenata Rüppell, 1830. Whereas from the transect only obtained 41 numbers of species and 65 numbers of individual and around 3 dominant species namely Metopograpsus messor (Forskål, 1775), Tubuca coarctata (H. Milne Edwards, 1852) and Pilumnus tomentosus Latreille, 1825 (Table S3).

Table 3. Number of species and number of individual from tree location trawlings of crustaceans in the waters of the Natuna Islands

\begin{tabular}{lllll}
\hline Parameter & $\begin{array}{l}\text { Trawl 1/sta 14 (Sedanau } \\
\text { Island) }\end{array}$ & $\begin{array}{l}\text { Trawl 2/sta 16 (Batang } \\
\text { Island) }\end{array}$ & $\begin{array}{l}\text { Trawl 3/sta 20 (Bunguran } \\
\text { Island) }\end{array}$ & Total \\
\hline Total of Species & 31 & 15 & 20 & 66 \\
Total of Individuals & 410 & 125 & 211 & 746 \\
\hline
\end{tabular}


Based on the results of the free collection in the mangrove area, crustacean species were found which are dominated by the Sesarmidae, Ocypodidae, and Coenobitidae families. This is in accordance with research conducted by Ravichandran et al. 2011, their research showed that $U c a$ spp. found mostly in mangrove forests and is a dominant species compared to other crustacean species. In general, $U c a$ spp. often found with very large number of species in open areas and has an important role in the mangrove forest ecosystem. While other crab species, such as the Paguridae and Xanthidae families, were also found at the study site, but they were not numerous. Their presence is thought to be just to find food and shelter for while. In this study the crab of Scylla spp. rarely found in the study site. Possibility this shows that the destruction of mangrove vegetation at the study site has caused disruption of the mangrove ecosystem and caused an ecological stability to have an impact on the decline in crab species in the area. In addition, crabs in the mangrove area can adapt well if there is a environmental changes in their habitat, they will migrate quickly when their habitat is disturbed. The dominant crab species at the study site was Parasesarma plicatum species (Latreille, 1803), and Parasesarma pictum (De Haan, 1835) are most commonly found in mangrove forests in intertidal areas with a total of 42 and 48 individuals. However, this species cannot be consumed. Both species has the ability to adapt to the surrounding environment both in damaged or extreme conditions. Besides that according to (Salgado and Keith 2010), this species has a habit of eating litter and even mangrove seeds.

The conclusion that can be drawn from this study is that, there needs to be thought about the tools and methods that will be used in the research. The location, habitat and environment around the research site must also be presurveyed before the research is conducted. The results from research in a location will work well, if done in accordance with the right tools and methods.

\section{ACKNOWLEDGEMENTS}

This project was funded by Indonesian government through DIPA for RC. Oceanography-LIPI under project Widya Nusantara Expedition (EWIN) year 2011-2012. Thanks to Muswery Mochtar as a leader and thanks to crustacean team survey of project "EWIN" for their field assistance. Thanks to my junior Mariana Destila Bayu Intan for the drawing process.

\section{REFERENCES}

Alfitriatussulus. 2003. Sebaran Moluska (Bivalvia dan Gastropoda) di Muara Sungai Cimandiri, Teluk Pelabuhan Ratu, Sukabumi, Jawa Barat. [Hon. Thesis]. Fakultas Perikanan dan Kelautan. Institut Pertanian Bogor, Bogor. [Indonesian]

Ahyong S, Moosa MK. 2004. Stomatopod Crustacea from Anambas and Natuna Islands, South China Sea, Indonesia. Raffles B Zool Suppl 11 : 61-66.
Banner AH, Banner DM. 1966. The alpheid shrimps of Thailand: The alpheid shrimp of Gulf of Thailand and adjacent waters. Siam Soc Monograph Ser 3 (6): 168.

Banner DM, Banner AH. 1982. The alpheid shrimp of Australia, Part III: The remaining Alpheids, principally the Genus Alpheus, and the family Ogyrididae. The Alpheid shrimp of Australia. Supplement I. Rec Aus Mus 34 (1-2): 1-363.

Banner DM, Banner A H. 1985. The Alpheid shrimp of Indonesia, based upon J.G. De Man's."The Decapoda of the Siboga Expedition, Part II. Family Alpheidae” (1911). Mar Res Indones 25, 79 pp.

Bezerra LEA, Almeida AO. 2008. Notes On Geographic Distribution Crustacea, Decapoda, Caridea, Alpheidae, Alpheus simus GuérinMéneville, 1856: Further report from Brazilian waters. Check List 4 (1): 57-61.

Burukovskii RN. 1982. Key to shrimps and lobsters. Oxonian Press PVT LTD. New Delhi, India.

Chace F Ajr. 1988. The Caridean shrimps (Crustacea: Decapoda) of the Albatros Philippine Expedition, 1907-1910, Part 5: Family Alpheidae. Smithson Contrib Zool 466: 99. Smithsonian Institution Press, Washington, D.C

Dai A,Yang S. 1991. Crabs of the China Seas. China Ocean Press, Beijing and Springer-Verlag, Berlin.

de Man JG. 1892. Decapoda des indischen Archipels. In: Weber M (ed) Zoologische Ergebnisse einer Reise in Niederlandisch Ost-Indien. Brill, Leiden.

de Man JG. 1902. Die von Herrn Professor Kükenthal im Indischen Archipel gesammelten Dekapoden und Stomatopoden. Abh Senckenb Naturforsch Ges 25: 467-929.

de Man JG. 1911. The Decapoda of the Siboga Expedition, Part II: The Alpheidae. Siboga Expeditie.

Frith DW. Tantanasiriwong RR, Bhatia O. 1976. Zonation of macrofauna on a mangrove shore, Phuket Island. Phuket Mar Biol Center Res Bull 10: $1-37$.

Hall DNF. 1962. Observation on the taxonomy and biology of some Indo West Pasific Penaeidae (Crustacea-Decapoda). Field. Publication Colonial of London.

Hamidy R. 2010. Struktur dan keragaman komunitas kepiting di kawasan hutan mangrove stasiun kelautan Universitas Riau, Desa Purnama Dumai. Ilmu Lingkungan J Environ Sci 2 (4): 81-91. [Indonesian]

Holthuis LB. 1955. The recent genera of the Caridean and Stenopodideae shrimps (Class crustacea, Order Decapoda Supersection Natantia) with keys for their determination. Rijksmuseum van Natuurlijke Historie, Leiden, Netherlands.

Kathiresan KBL, Bingham. 2001. Biology of mangrove and mangrove ecosystems. Mar Biol 40, 81-251.

Kathiresan K, Kandasamy S, Raj A, Venugopal G. 2016. A simple method for assessing mangrove forest based on young plants and sesarmid crab holes. J Adv Mar Biol 7: 204-210.

Katili AS, Utina R, Mopangga NL. 2017. Short communication: Crab species distribution under mangrove stands in Tabongo, Gorontalo Province, Indonesia. Biodiversitas 18: 520-524.

Kim W, Abele G. 1988. The Snapping Shrimp Genus Alpheus from the Eastern Pacific (Decapoda: Caridea: Alpheidae). Smithsonian Contributions to Zoology. Smithsonian Institute Press, Washington D.C.

Lapolo N, Utina R, Badaren DWK. 2018. Diversity and density of crabs in degraded mangrove area at Tanjung Panjang nature reverse in Gorontalo, Indonesia. Biodivesitas 19 (3): 1154-1159.

Li X. 2004. The Pontoniine Shrimps (Crustacea: Decapoda: Palaemonidae) from Anambas and Natuna Islands, Indonesia Collected by Anambas Expedition, 2002. Raffles Bull Zool Suppl 11: 67-72.

Mirmanto E. 2014. Komposisi floristik dan struktur hutan di Pulau Natuna Besar, Kepulaun Natuna. Jurnal Biologi Indonesia 10 (2): 201-211. [Indonesian]

Moosa MK, Juwana S. 1996. Kepiting Suku Portunidae dari Perairan Indonesia (Decapoda, Brachyura). Pusat Penelitian dan Pengembangan Oseanologi. Lembaga Ilmu Pengetahuan Indonesia, Jakarta. [Indonesian]

Nirmala IW, Pratiwi R. 2011. Distribusi spatial krustasea di perairan kepulauan Matasiri, Kalimantan Selatan. Ilmu Kelautan 16 (3): 125134. [Indonesian]

$\mathrm{Ng}$ PKL, Keng WL, Lim KKP. 2008. Private lives an expose of Singapore's Mangroves. Raffles Mus Biodivers Res, Singapapore. 
Pramonowibowo AA, Hartoko, Ghofar A. 2007. Kepadatan udang putih (Penaeus merguiensis De Man) di sekitar perairan Semarang. Jurnal Pasir Laut 2 (2): 18-29. [Indonesian]

Pratiwi R 1999. Katalog koleksi biota laut. Puslitbang Oseanologi Jilid I. (Ikan, Koralia dan Krustasea). Pusat Penelitian dan Pengembangan Oseanologi-Lembaga Ilmu Pengetahuan Indonesia. [Indonesian]

Pratiwi R. 2002. The Alpheids shrimps from Seribu Islands and Banten Bay, Indonesian Waters (Crustacea, Decapoda, Alpheidae); Procceding of The JSPS-DGHE International Seminar on Crustacean Fisheries (Biology, Technology and Management. Bogor Indonesia, August 20-21, 2002.

Pratiwi R. 2006. Keanekaragaman jenis udang Alpheus spp. di Kepulauan Seribu dan Teluk Banten. OLDI, 40: 1-14. [Indonesian].

Pratiwi R. 2010. Asosiasi krustasea di ekosistem padang lamun perairan Teluk Lampung. Ilmu Kelautan. Indones J Mar Sci 15 (2): 59-118. [Indonesian]

Prodam R, Ng PKL. 2009. Lithoselatium tantichodoki, a new species of intertidal crab (Crustacea: Brachyura: Sesarmidae) from southern Thailand. Zootaxa 2291: 24-34.

Rahayu DL, Davie PJF. 2002. Two new species and a new record of Perisesarma (Decapoda: Brachyura: Grapsidae, Sesarmidae) from Indonesia. Crustaceana 75 (3-4): 597-607.

Rahayu DL, Setyadi G. 2009. Mangrove estuary crabs of The Mimika Region, Papua, Indonesia. PT Freeport Indonesia-LIPI, Papua. [Indonesian]

Ravichandran W, Sylvester F, Khan SA, Balasubramanian T. 2011. Diversity of mangrove crabs in South and South East Asia J Oceanogr Mar Environ Syst 1 (1): 1-7.

Romimohtarto K, Juwana S. 2001. Biologi Laut. Ilmu pengetahuan tentang biota laut. Pusat Penelitian dan Pengembangan OseanologiLIPI, Jakarta. [Indonesian]

Sasekumar A. 1974. Distribution of macrofauna on a Malayan mangrove shore. J Anim Ecol 43: 5-69.

Salgado CK, Keith M. 2010. Spatial and temporal variation in relative numbers of grapsid crabs (Decapoda: Grapsidae) in northern Australian mangrove forests. Beagle 26: 79-87.
Sakai T. 1976. Crabs of Japan and the Adjacent Seas Plates. Kodarian Ltd, Japan.

Schubart CD, Liu H, Ng PKL. 2009. Revision of Selatium Serene \& Soh, 1970 (Crustacea: Brachyura: Sesarmidae) with descrption of a new genus and two new species. Zootaxa 2154: 1-29.

Stephenson W. 1972. An annotated check-list and key to the Indo-westPacific swimming crabs (Crustacea: Decapoda: Portunidae). Bull R Soc N Z 10: 1-64.

Stephenson W. 1975. Biological results of the Snellius expedition. XXVI. The Portunidae (Decapoda-Brachyura) of the Snellius expedition (Part II). Zool Meded 49 (14): 173-206.

Tiwari KK. 1963. Alpheid shrimps (Crustacea: Decapoda: Alpheidae) of Vietnam. Ann Fac Sci Saigon 269-362.

Trivedi DJ, Trivedi JN, Soni GM, Purohit BD, Vachhrajani KD. 2015. Crustacean fauna of Gujarat state of India: A review. Electron J Environ Sci 8: 23-31.

Toro V, Soegiarto KA. 1979. Biologi Udang. In: Soegiarto A, Toro V, Soegiarto KA (eds) Udang. Biologi, potensi, budidaya, produksi dan udang sebagai bahan makanan di Indonesia. Proyek Penelitian Potensi Sumber Daya Ekonomi. Lembaga Oseanologi Nasional-LIPI, Jakarta. [Indonesian]

Wicksten MK, McClure MR. 2007. Snapping shrimps (Decapoda: Caridea: Alpheidae) from the Dampier Archipelago, western Australia. Rec West Aust Mus Suppl 73: 61-73.

Widyastuti E. 2007. Fauna Krustasea di Perairan Kepulauan Anambas, Propinsi Kepulauan Riau. Biosfera 24 (1): 10-16. [Indonesian]

Widyastuti E. 2016. Keanekaragaman kepiting pada ekosistem mangrove di perairan Lingga Utara dan sekitarnya, Kepulauan Riau. Zoo Indonesia 25 (1): 22-32. [Indonesian]

Wong KH, Chan BKK. 2011. Two new species of sand bubbler crabs, Scopimera from North China and the Philippines (Crustacea: Decapoda: Dotillidae). Zootaxa 2962: 21-35.

Yeo DC, Rahayu DL, Ng PKL. 2004. Brachyura (Crustacea) of the Anambas Expedition 2002. Raffles Bull Zool Suppl 11: 79-88. 
Table S1. The total species of crustacean fauna obtained from Natuna islands using three different methods

\begin{tabular}{|c|c|c|c|c|}
\hline \multirow{2}{*}{ Family } & \multirow[b]{2}{*}{ Genus/spesies } & \multicolumn{3}{|c|}{ Sampling methods } \\
\hline & & Trawl & Transect & $\begin{array}{c}\text { Free } \\
\text { collections }\end{array}$ \\
\hline \multirow[t]{3}{*}{ Alpheidae } & Alpheus facetus & 1 & 4 & 9 \\
\hline & Alpheus rapax & 4 & 1 & 1 \\
\hline & Alpheus lottini & 3 & 0 & 4 \\
\hline \multirow[t]{2}{*}{ Callapidae } & Ashtoret lunaris & 0 & 2 & 3 \\
\hline & Calappa sp. & 0 & 0 & 2 \\
\hline Coenobitidae & Coenobita rugosus & 0 & 4 & 33 \\
\hline \multirow[t]{5}{*}{ Grapsidae } & Grapsus albolineatus & 0 & 1 & 23 \\
\hline & Grapsus longitarsis & 0 & 0 & 2 \\
\hline & Grapsus sp. & 0 & 0 & 10 \\
\hline & Grapsus tenuicrustatus & 0 & 0 & 16 \\
\hline & Metopograpsus messor & 0 & 5 & 22 \\
\hline \multirow{12}{*}{$\begin{array}{l}\text { Hapalo- } \\
\text { carcinidae } \\
\text { Larvae } \\
\text { Leucosiidae }\end{array}$} & $\begin{array}{l}\text { Hapalocarcinus } \\
\text { marsupialis }\end{array}$ & 0 & 0 & 2 \\
\hline & White shrimps larvae (?) & 0 & 0 & 60 \\
\hline & Arcania gracilis & 3 & 0 & 0 \\
\hline & Arcania heptacantha & 1 & 0 & 0 \\
\hline & $\begin{array}{l}\text { Arcania } \\
\text { undecimspinosa }\end{array}$ & 1 & 0 & 0 \\
\hline & $I x a \mathrm{sp}$. & 2 & 0 & 0 \\
\hline & Ixoides sp. & 1 & 0 & 0 \\
\hline & Leucosia sp. & 1 & 0 & 0 \\
\hline & Liagore sp. & 3 & 0 & 0 \\
\hline & Liomera cinctimanus & 0 & 1 & 1 \\
\hline & Pariphiculus coronatus & 1 & 0 & 0 \\
\hline & Randallia eburnea & 1 & 0 & 0 \\
\hline \multirow[t]{3}{*}{ Majidae } & Myra fugax & 1 & 0 & 0 \\
\hline & Myra sp. & 1 & 0 & 0 \\
\hline & Phalangipus hystrix & 83 & 0 & 0 \\
\hline \multirow[t]{4}{*}{ Ocypodidae } & Ocypode cordimana & 0 & 2 & 21 \\
\hline & $\begin{array}{l}\text { Ocypode } \\
\text { ceratopthalmus }\end{array}$ & 0 & 4 & 36 \\
\hline & $\begin{array}{l}\text { Uca }(\text { Tubuca }) \\
\text { coarctata }\end{array}$ & 0 & 10 & 20 \\
\hline & $\begin{array}{l}\text { Uca (Austruca) } \\
\text { annulipes }\end{array}$ & 0 & 3 & 2 \\
\hline Parthenopidae & Parthenope contrarius & 0 & 0 & 1 \\
\hline \multirow[t]{2}{*}{ Paguridae } & Clibanarius sp. & 0 & 0 & 12 \\
\hline & Pagurus sp. & 0 & 0 & 41 \\
\hline \multirow[t]{8}{*}{ Penaeidae } & Metapenaeus ensis & 27 & 0 & 0 \\
\hline & $\begin{array}{l}\text { Metapenaeopsis } \\
\text { palmensis }\end{array}$ & 246 & 0 & 0 \\
\hline & $\begin{array}{l}\text { Metapenaeopsis } \\
\text { andamanensis }\end{array}$ & 73 & 0 & 0 \\
\hline & $\begin{array}{l}\text { Megokris } \\
\text { pescadoreensis }\end{array}$ & 19 & 0 & 0 \\
\hline & Penaeus merguiensis & 20 & 0 & 0 \\
\hline & Penaeus monodon & 25 & 0 & 0 \\
\hline & Penaeus semisulcatus & 3 & 0 & 0 \\
\hline & $\begin{array}{l}\text { Trachysalambria } \\
\text { curvirostris }\end{array}$ & 23 & 0 & 0 \\
\hline \multirow[t]{5}{*}{ Portunidae } & $\begin{array}{l}\text { Charybdis (Charybdis) } \\
\text { acuta }\end{array}$ & 0 & 0 & 21 \\
\hline & $\begin{array}{l}\text { Charybdis callianassa } \\
\text { Charybdis }\end{array}$ & 52 & 0 & 0 \\
\hline & $\begin{array}{l}\text { (Goniohellenus) } \\
\text { truncata }\end{array}$ & 0 & 0 & 24 \\
\hline & Charybdis sp. 1 & 1 & 0 & 0 \\
\hline & $\begin{array}{l}\text { Portunus (Monomia) } \\
\text { gladiator }\end{array}$ & 4 & 0 & 0 \\
\hline
\end{tabular}

Portunus

(Cycloachelous) $\quad 3 \quad 0 \quad 0$

granulatus

Portunus (Portunus) $\quad 0 \quad 0 \quad 13$

pelagicus

Portunus

sanguinolentus $\quad 0 \quad 0 \quad 6$

$\begin{array}{llll}\text { Portunus (Xiphonectes) } & 0 & 0 & 4 \\ \text { tenuipes }\end{array}$

$\begin{array}{llll}\text { Thalamita crenata } & 3 & 2 & 19\end{array}$

Thalamita prymna $\quad 0 \quad 0 \quad 35$

Sesarmidae Parasesarma plicatum 000042

$\begin{array}{llll}\text { Parasesarma pictum } & 0 & 1 & 48\end{array}$

$\begin{array}{lllll}\text { Scyllaridae } & \text { Eduarctus martensii } & 2 & 0 & 0\end{array}$

$\begin{array}{llll}\text { Thenus orientalis } & 5 & 0 & 0\end{array}$

$\begin{array}{lllll}\text { Scyoiidae } & \text { Sicyonia ocellata } & 3 & 0 & 0\end{array}$

Squillidae Oratosquillina $\quad 1 \quad 000$

inornata

Oratosquilla nepa $\quad 14 \quad 0 \quad 0$

Oratosquilla sp. $1 \quad 2 \quad 0 \quad 0$

Oratosquilla sp. $2 \quad 5 \quad 0 \quad 0$

Oratosquilla sp. $3 \quad 1 \quad 000$

$\begin{array}{llll}\text { Oratosquilla } \text { sp. } 4 & 3 & 0 & 0\end{array}$

$\begin{array}{llll}\text { Oratosquilla } \text { sp. } 5 & 2 & 0 & 0\end{array}$

Quollastria ornata $\quad 6 \quad 0 \quad 0$

$\begin{array}{lllll}\text { Xanthidae } & \text { Actae sp. } & 0 & 1 & 2\end{array}$

$\begin{array}{llll}\text { Atergatis floridus } & 0 & 2 & 1\end{array}$

Baptozius vinosus $\quad 0 \quad 0 \quad 5$

Chlorodiella nigra $\quad 0 \quad 2 \quad 2$

$\begin{array}{llll}\text { Etisus sp. } & 0 & 0 & 11\end{array}$

Euxanthus exsculptus $\quad 0 \quad 2 \quad 4$

Pilumnus longicornis $\quad 0 \quad 0 \quad 0 \quad 4$

Pilumnus tomentosus $\quad 0 \quad 4 \quad 16$

Total of species

$\begin{array}{lll}66 & 41 & 101\end{array}$

$\begin{array}{llll}\text { Total of individu } & 746 & 65 & 704\end{array}$

4


Table S2. Fauna of crustacean obtained tree times from trawling

\begin{tabular}{|c|c|c|c|c|c|}
\hline \multirow[b]{2}{*}{ Family } & \multirow[b]{2}{*}{ Genus/Spesies } & \multicolumn{3}{|c|}{ Sampling methods } & \multirow[b]{2}{*}{ Total } \\
\hline & & $\begin{array}{c}\text { Trawl } \\
1\end{array}$ & $\begin{array}{c}\text { Trawl } \\
2\end{array}$ & $\begin{array}{c}\text { Trawl } \\
\mathbf{3}\end{array}$ & \\
\hline \multirow[t]{3}{*}{ Alpheidae } & Alpheus facetus & 0 & 0 & 1 & 1 \\
\hline & Alpheus lottini & 0 & 0 & 4 & 4 \\
\hline & Alpheus rapax & 3 & 0 & 0 & 3 \\
\hline \multirow[t]{10}{*}{ Leucosiidae } & Arcania gracilis & 0 & 3 & 0 & 3 \\
\hline & Arcania heptacantha & 0 & 0 & 1 & 1 \\
\hline & Arcania undecimspinosa & 0 & 1 & 0 & 1 \\
\hline & Ixa sp. & 2 & 0 & 0 & 2 \\
\hline & Ixoides sp. & 0 & 1 & 0 & 1 \\
\hline & Leucosia sp. & 1 & 0 & 0 & 1 \\
\hline & Liagore sp. & 0 & 3 & 0 & 3 \\
\hline & Pariphiculus coronatus & 1 & 0 & 0 & 1 \\
\hline & Psopheticus hughis & 0 & 1 & 0 & 1 \\
\hline & Randallia eburnea & 1 & 0 & 0 & 1 \\
\hline \multirow{3}{*}{ Majidae } & Myra fugax & 1 & 0 & 0 & 1 \\
\hline & Myra sp. & 0 & 0 & 1 & 1 \\
\hline & Phalangipus hystrix & 83 & 0 & 0 & 83 \\
\hline \multirow{8}{*}{ Penaeidae } & Metapenaeus ensis & 27 & 0 & 0 & 27 \\
\hline & $\begin{array}{l}\text { Metapenaeopsis } \\
\text { palmensis }\end{array}$ & 145 & 73 & 28 & 246 \\
\hline & $\begin{array}{l}\text { Metapenaeopsis } \\
\text { andamanensis }\end{array}$ & 20 & 25 & 18 & 63 \\
\hline & Megokris pescadoreensis & 7 & 0 & 12 & 19 \\
\hline & Penaeus merguiensis & 20 & 0 & 0 & 20 \\
\hline & Penaeus monodon & 25 & 0 & 0 & 25 \\
\hline & Penaeus semisulcatus & 3 & 0 & 0 & 3 \\
\hline & $\begin{array}{l}\text { Trachysalambria } \\
\text { curvirostris }\end{array}$ & 23 & 0 & 0 & 23 \\
\hline \multirow[t]{12}{*}{ Portunidae } & $\begin{array}{l}\text { Charybdis (Charybdis) } \\
\text { acuta }\end{array}$ & 0 & 0 & 21 & 21 \\
\hline & Charybdis callianassa & 3 & 4 & 45 & 52 \\
\hline & Charybdis sp. 1 & 2 & 0 & 0 & 2 \\
\hline & $\begin{array}{l}\text { Portunus (Monomia) } \\
\text { gladiator }\end{array}$ & 1 & 0 & 0 & 1 \\
\hline & Portunus & & & & \\
\hline & $\begin{array}{l}\text { (Cycloachelous) } \\
\text { granulatus }\end{array}$ & 14 & 0 & 0 & 14 \\
\hline & $\begin{array}{l}\text { Portunus (Portunus) } \\
\text { pelagicus }\end{array}$ & 0 & 0 & 1 & 1 \\
\hline & $\begin{array}{l}\text { Portunus } \\
\text { sanguinolentus }\end{array}$ & 0 & 0 & 6 & 6 \\
\hline & $\begin{array}{l}\text { Portunus } \\
\text { (Xiphonectes) tenuipes }\end{array}$ & 4 & 0 & 0 & 4 \\
\hline & Thalamita crenata & 3 & 2 & 19 & 24 \\
\hline & Thalamita mitsiensis & 0 & 0 & 2 & 2 \\
\hline & Thalamita prymna & 0 & 0 & 35 & 35 \\
\hline \multirow[t]{3}{*}{ Scyllaridae } & Eduarctus martensii & 2 & 0 & 0 & 2 \\
\hline & Scyllarides latus & 3 & 0 & 0 & 3 \\
\hline & Thenus orientalis & 1 & 1 & 3 & 5 \\
\hline Scyoiidae & Sicyonia ocellata & 1 & 4 & 3 & 8 \\
\hline \multirow[t]{7}{*}{ Squillidae } & Oratosquillina inornata & 1 & 0 & 0 & 1 \\
\hline & Oratosquilla nepa & 7 & 4 & 3 & 14 \\
\hline & Oratosquilla sp. 1 & 1 & 1 & 0 & 2 \\
\hline & Oratosquilla sp. 2 & 1 & 0 & 4 & 5 \\
\hline & Oratosquilla sp. 3 & 1 & 0 & 0 & 1 \\
\hline & Oratosquilla sp. 4 & 0 & 1 & 2 & 3 \\
\hline & Quollastria ornata & 3 & 1 & 2 & 6 \\
\hline \multicolumn{2}{|c|}{ Total of species } & 31 & 15 & 20 & 66 \\
\hline \multicolumn{2}{|c|}{ Total of individu } & 410 & 125 & 211 & 746 \\
\hline
\end{tabular}

Table S3. Crustacean fauna obtained from transects

\begin{tabular}{|c|c|c|c|c|c|}
\hline \multirow{3}{*}{ Family } & \multirow{3}{*}{ Genus/spesies } & \multicolumn{3}{|c|}{ Station } & \multirow{3}{*}{ Total } \\
\hline & & TRSCT & TRSCT & TRSCT & \\
\hline & & 1 & 2 & 3 & \\
\hline \multirow[t]{3}{*}{ Alpheidae } & Alpheus facetus & 1 & 2 & 1 & 4 \\
\hline & Alpheus rapax & 1 & 0 & 0 & 1 \\
\hline & Apheus lottini & 0 & 0 & 0 & 0 \\
\hline \multirow[t]{2}{*}{ Callapidae } & Ashtoret lunaris & 0 & 2 & 0 & 2 \\
\hline & Calappa sp. & 0 & 0 & 0 & 0 \\
\hline Coenobitidae & Coenobita rugosus & 0 & 2 & 2 & 4 \\
\hline Dromiidae & Frodromia atypica & 1 & 0 & 0 & 1 \\
\hline \multirow[t]{5}{*}{ Grapsidae } & $\begin{array}{l}\text { Grapsus } \\
\text { albolineatus }\end{array}$ & 0 & 0 & 1 & 1 \\
\hline & Grapsus sp. & 2 & 2 & 1 & 5 \\
\hline & Metopograpsus messor & 4 & 3 & 3 & 10 \\
\hline & Grapsus tenuicrustatu & 0 & 0 & 0 & 0 \\
\hline & Grapsus longitarsis & 0 & 1 & 1 & 2 \\
\hline Leoucosiidae & Liomera cinctimanus & 0 & 0 & 1 & 1 \\
\hline \multirow[t]{2}{*}{ Sesarmidae } & Parasesarma plicatun & 0 & 0 & 0 & 0 \\
\hline & Parasesarma pictum & 1 & 0 & 0 & 1 \\
\hline \multirow[t]{4}{*}{ Ocypodidae } & Ocypode cordimana & 1 & 0 & 1 & 2 \\
\hline & Ocypode ceratopthalm & 1 & 2 & 1 & 4 \\
\hline & $\begin{array}{l}\text { Uca }(\text { Tubuca }) \\
\text { coarctata }\end{array}$ & 1 & 5 & 4 & 10 \\
\hline & $\begin{array}{l}\text { Uca (Austruca) } \\
\text { annulipes }\end{array}$ & 0 & 1 & 2 & 3 \\
\hline \multirow[t]{2}{*}{ Paguridae } & Clibanarius sp. & 0 & 0 & 0 & 0 \\
\hline & Pagurus sp. & 0 & 0 & 0 & 0 \\
\hline Parthenopidae & Parthenope sp. & 0 & 0 & 0 & 0 \\
\hline \multirow[t]{9}{*}{ Portunidae } & Scylla serrata & 0 & 0 & 0 & 0 \\
\hline & Thalamita admete & 0 & 0 & 0 & 0 \\
\hline & Thalamita crenata & 0 & 1 & 1 & 2 \\
\hline & Thalamita prymna & 0 & 0 & 0 & 0 \\
\hline & Thalamita mitisensis & 0 & 0 & 0 & 0 \\
\hline & $\begin{array}{l}\text { Charybdis } \\
\text { (Charybdis) acuta } \\
\text { Charybdis }\end{array}$ & 0 & 0 & 0 & 0 \\
\hline & $\begin{array}{l}\text { (Goniohellenus) } \\
\text { truncata }\end{array}$ & 0 & 0 & 0 & 0 \\
\hline & $\begin{array}{l}\text { Portunus (Portunus) } \\
\text { pelagicus }\end{array}$ & 0 & 0 & 0 & 0 \\
\hline & $\begin{array}{l}\text { Portunus } \\
\text { sanguinolentus }\end{array}$ & 0 & 0 & 0 & 0 \\
\hline \multirow[t]{10}{*}{ Xanthidae } & Atergatis floridus & 1 & 1 & 0 & 2 \\
\hline & Actae sp. & 0 & 0 & 1 & 1 \\
\hline & Liomera sp. & 0 & 0 & 1 & 1 \\
\hline & Chlorodiella nigra & 1 & 0 & 1 & 2 \\
\hline & Etisus sp. & 0 & 0 & 0 & 0 \\
\hline & $\begin{array}{l}\text { Euxanthus } \\
\text { exsculptus }\end{array}$ & 0 & 2 & 0 & 2 \\
\hline & Pilumnus tomentosus & 2 & 1 & 1 & 4 \\
\hline & $\begin{array}{l}\text { Pilumnus } \\
\text { longicornis }\end{array}$ & 0 & 0 & 0 & 0 \\
\hline & Baptozius vinosus & 0 & 0 & 0 & 0 \\
\hline & Cardisoma sp. & 0 & 0 & 0 & 0 \\
\hline $\begin{array}{l}\text { Hapalo- } \\
\text { carcinidae }\end{array}$ & $\begin{array}{l}\text { Hapalocarcinus } \\
\text { marsupialis }\end{array}$ & 0 & 0 & 0 & 0 \\
\hline Larva & $\begin{array}{l}\text { White shrimps } \\
\text { larvae (?) }\end{array}$ & 0 & 0 & 0 & 0 \\
\hline \multicolumn{2}{|c|}{ Total number of species } & 12 & 13 & 16 & 41 \\
\hline \multicolumn{2}{|c|}{ Total number of individuals } & 17 & 25 & 23 & 65 \\
\hline
\end{tabular}


Table S4. Crustacean fauna obtained from free collections

\begin{tabular}{|c|c|c|c|c|c|}
\hline \multirow{2}{*}{$\begin{array}{l}\text { Family } \\
\text { Alpheidae }\end{array}$} & \multirow{2}{*}{$\begin{array}{l}\text { Genus/Spesies } \\
\text { Alpheus facetus }\end{array}$} & \multicolumn{3}{|c|}{ FC 1 FC 2 FC 3} & Tota \\
\hline & & 3 & 3 & 4 & 9 \\
\hline & Alpheus rapax & 1 & 0 & 0 & 1 \\
\hline & Alpheus lottini & 3 & 2 & 2 & 7 \\
\hline \multirow{2}{*}{ Callapidae } & Ashtoret lunaris & 2 & 1 & 2 & 5 \\
\hline & Callapa sp. & 0 & 1 & 1 & 2 \\
\hline \multirow[t]{2}{*}{ Coenobitidae } & Coenobita rugosus & 6 & 10 & 25 & 41 \\
\hline & Pagurus sp. & 5 & 15 & 13 & 33 \\
\hline \multirow[t]{5}{*}{ Grapsidae } & Grapsus albolineatus & 8 & 12 & 3 & 23 \\
\hline & Metopograpsus messor & 14 & 7 & 6 & 27 \\
\hline & Grapsus sp. & 6 & 1 & 3 & 10 \\
\hline & Grapsus tenuicrustatus & 2 & 6 & 8 & 16 \\
\hline & Grapsus longitarsis & 2 & 0 & 0 & 2 \\
\hline Leoucosiidae & Liomera cinctimanus & 1 & 0 & 0 & 1 \\
\hline \multirow{4}{*}{ Ocypodidae } & Ocypode cordimana & 6 & 13 & 2 & 21 \\
\hline & Ocypode ceratopthalmus & 12 & 9 & 15 & 36 \\
\hline & Uca coarctata & 2 & 8 & 10 & 20 \\
\hline & Uca annulipes & 0 & 2 & 0 & 2 \\
\hline Paguridae & Clibanarius sp. & 1 & 4 & 7 & 12 \\
\hline Parthenopidae & Parthenope sp. & 0 & 1 & 0 & 1 \\
\hline \multirow[t]{8}{*}{ Portunidae } & Thalamita crenata & 20 & 13 & 12 & 45 \\
\hline & Thalamita admete & 1 & 6 & 4 & 11 \\
\hline & Thalamita prymna & 2 & 5 & 10 & 35 \\
\hline & Thalamita mitisensis & 2 & 0 & 0 & 2 \\
\hline & $\begin{array}{l}\text { Charybdis (Charybdis) } \\
\text { acuta }\end{array}$ & 3 & 0 & 18 & 21 \\
\hline & $\begin{array}{l}\text { Charybdis } \\
\text { (Goniohellenus) } \\
\text { truncata }\end{array}$ & 11 & 5 & 8 & 24 \\
\hline & $\begin{array}{l}\text { Portunus (Portunus) } \\
\text { pelagicus }\end{array}$ & 3 & 5 & 5 & 13 \\
\hline & Portunus sanguinolentus & 0 & 1 & 5 & 6 \\
\hline \multirow[t]{2}{*}{ Sesarmidae } & Parasesarma plicatum & 9 & 14 & 20 & 42 \\
\hline & Parasesarma pictum & 8 & 19 & 21 & 48 \\
\hline \multirow[t]{11}{*}{ Xanthidae } & Atergatis floridus & 1 & 0 & 0 & 1 \\
\hline & Actae sp. & 2 & 0 & 0 & 2 \\
\hline & Liomera sp. & 1 & 0 & 0 & 1 \\
\hline & Chlorodiella nigra & 0 & 2 & 0 & 2 \\
\hline & Etisus sp. & 10 & 0 & 1 & 11 \\
\hline & Euxanthus exsculptus & 1 & 3 & 2 & 6 \\
\hline & Pilumnus tomentosus & 5 & 3 & 8 & 16 \\
\hline & Pilumnus longicornis & 3 & 1 & 0 & 4 \\
\hline & Pilumnus sp. & 0 & 1 & 0 & 1 \\
\hline & Baptozius vinosus & 2 & 3 & 0 & 5 \\
\hline & Cardisoma sp. & 1 & 2 & 0 & 3 \\
\hline $\begin{array}{l}\text { Hapalo- } \\
\text { carcinidae }\end{array}$ & $\begin{array}{l}\text { Hapalocarcinus } \\
\text { marsupialis }\end{array}$ & 0 & 1 & 1 & 2 \\
\hline Larva & White shrimps larvae (?) & $\mathbf{0}$ & 60 & 0 & 60 \\
\hline \multicolumn{2}{|c|}{ Total number of species } & 36 & 35 & 30 & 101 \\
\hline \multicolumn{2}{|c|}{ Total number of individuals } & 171 & 269 & 264 & 704 \\
\hline
\end{tabular}


BIODIVERSITAS

Volume 21, Number 3, March 2020

Pages: 1215-1226
ISSN: 1412-033X

E-ISSN: 2085-4722

DOI: 10.13057/biodiv/d210349 